\title{
Comparison of Serum Magnesium Levels in Patients with Erectile Dysfunction and Healthy Peers
}

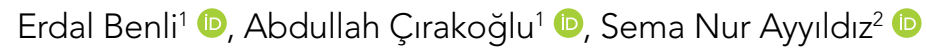 \\ 'Department of Urology, Ordu University School of Medicine, Ordu, Turkey \\ ${ }^{2}$ Clinic of Biochemistry, Ankara Traning and Research Hospital, Ankara, Turkey
}

Cite this article as: Benli E, Çırakoğlu A, Ayyıldız SN. Comparison of Serum Magnesium Levels in Patients with Erectile Dysfunction and Healthy Peers. JAREM 2018; 8: 25-9.

\begin{abstract}
Objective: Erectile dysfunction (ED) is a very common health problem among men that disrupts the quality of life. The aim of this study was to investigate whether serum magnesium levels in patients with ED are different from those in healthy individuals.

Methods: The study accessed the data of 344 patients who applied to the urology clinic from 2014 to 2016. Patients were divided into two groups: patients with ED, Group 1 ( $n=155)$ and those without ED, Group 2 (control; $n=189$ ). Characteristics such as patients' age, additional diseases, and smoking habits were recorded and compared between the two groups along with laboratory parameters such as levels of serum magnesium, calcium, and inflammatory markers. Sexual situation was assessed with the SHIM-5 form.

Results: Patients aged 63.15 \pm 8.90 years were included in Group 1 and those aged 61.63 \pm 8.01 years were included in Group 2 ( $p=0.101$ ). There were no differences between the groups in terms of BMI and waist circumference $(p>0.05)$. Serum magnesium levels were $1.94 \pm 0.20$ and $2.00 \pm 0.17 \mathrm{mg} / \mathrm{dl}$ in groups 1 and 2, respectively $(p=0.008)$. WBC value for inflammatory makers were $6.94 \pm 1.74$ and $6.58 \pm 1.43$ in groups 1 and 2 , respectively $(p=0.04)$.

Conclusion: Our study found that serum magnesium values were reduced in ED patients than in the control group. Therefore, it may be beneficial to determine serum magnesium values in ED patients. Additionally, serum magnesium values may be used as markers for the early identification of patients at risk.
\end{abstract}

Keywords: Erectile dysfunction, magnesium, marker

ORCID IDs of the authors: E.B. 0000-0001-8485-1424; A.Ç 0000-0002-8602-5836; S.N.A. 0000-0002-2354-2713

\section{INTRODUCTION}

Erectile dysfunction (ED) is defined as the inability to maintain an erection necessary for sexual intercourse, either repeatedly or continuously (1). The incidence of this disease, which increases with age, is approximately $20 \%-40 \%$ in the age range between 60 and 69 years, and it reaches $50 \%-100 \%$ in the age range between 70 and 80 years (2). As a part of the systemic vascular disease, it is believed that ED develops as a result of endothelial dysfunction in erectile tissues (3). The fact that systemic vascular disease first appears in the erectile tissue has been associated with the vessel diameter (penile vessel diameter 1-2 $\mathrm{mm}$, coronaries 3-4 mm). This may be because small-diameter vessels are more easily affected than large-diameter vessels (4). Therefore, any cause that affects the vascular function may trigger the ED development.

Magnesium (Mg) is among the most common cations in the cell, and it is necessary for the regular functioning of vascular smooth muscle cells. It is also known that it is required for the normal functioning of many physiological processes. In conducted studies, insulin sensitivity was associated with several pathologies such as diabetes, vascular disorders, and atherosclerosis (5-7). These results suggest a relationship between $\mathrm{Mg}$ and vascular functions. For this reason, we hypothesized that there might be a relationship between $\mathrm{Mg}$ and ED, which is known to develop as a vascular disorder. This study was designed to investigate the validity of such a hypothesis. To the best of our knowledge, this issue has not been examined in the literature before.

The aim of this study is to examine whether the level of Mg measured in the serum of the patients with ED is different from the level of healthy peers.

\section{METHODS}

The prospectively recorded data of 344 patients followed up in the urology clinic between 2014 and 2016 were evaluated retrospectively. This study has been approved by the Ordu University Local Ethics Committee (no: 40/2017). The laboratory results were obtained from the serum taken from the patients in the morning hours after 12-hour fasting. The patients were divided into two groups: Group $1(n=155)$ with ED and Group $2(n=189)$ that did not have ED and was used as control. Of the patients, ages, the body mass index (BMI), waist circumference, known diseases and laboratory parameters such as fasting blood glucose, Mg, Ca, C-reactive protein (CRP), white blood cells (WBC), and the neutrophil-lymphocyte ratio (Neu/Lym) were recorded. 
ED was defined as impairment or continuation of sexual intercourse for at least 3 months. There were questions in the form questioning the self-confidence of the patients in sexuality; the adequacy, frequency, and duration of erection; and the satisfaction with the sexual intercourse. For a complete urological evaluation, every patient who may have an ED risk routinely fills out the SHIM-5 form in our polyclinic. If the forms could not be filled out by patients or by their relatives, a health staff educated on this issue was there to help fill out the forms. These parameters were compared between the groups. The patients receiving treatment (phosphodiesterase type 5 inhibitor) for ED, those with kidney failure that could affect serum Mg values, those taking Mg supplementation, those suffering from depression that could cause sexual problems or from psychological diseases such as anxiety, and those receiving treatment for these diseases were excluded from the study. The control group consisted of patients who were admitted to our clinic with a complaint other than ED during the same time and whose data were recorded prospectively.

\section{Statistical Analysis}

Parameters with normal distribution were given as mean \pm standard deviation, and parameters without normal distribution were given as mean \pm interquartile range (IQR). The Kolmogorow-Smirnov test was used to evaluate the data with normal distribution. Student's t-test was used for the analysis of parametric data and the Mann-Whitney $U$ test for nonparametric data in the intergroup comparisons. In the correlation analysis, the Pearson test was used for the parametric data, and the Spearman correlation test was used for the nonparametric data. All statistical analyses were performed using the SPSS for Windows version 20.0 package program (IBM Statistical Package for Social Sciences Statistics, Armonk, NY, USA). The data with a $p$-value $<0.05$ were considered significant.

\section{RESULTS}

The distribution of age according to groups was found to be $63.15 \pm 8.90$ years for Group 1 (ED patients) and $61.63 \pm 8.01$ years for Group 2 (control) $(p=0.101)$. There were no differences between the groups in terms of lung disease, hypertension, smoking, and alcohol use $(p>0.05)$. Heart disease and diabetes mellitus were more common in patients with ED than the control group. This difference was statistically significant $(p<0.001$ and $p=0.002$, respectively). The distribution of the groups was similar in terms of the measurements of BMl and waist circumference ( $p>0.05$ ) (Table 1). The distribution of $\mathrm{Mg}$ among the diabetic and non-diabetic patient groups was $1.86 \pm 0.19$ and $2.00 \pm 0.17 \mathrm{mg} /$ $d L$, respectively $(p<0.001)$. The presence of hypertension or cardiac disease did not affect serum Mg levels ( $p>0.05)$.

The serum Mg level for Group 1 and Group 2 was found as $1.94 \pm 0.20$ and $2.00 \pm 0.17 \mathrm{mg} / \mathrm{dL}$, respectively $(p=0.008)$. Similarly, there was a relation between the serum $\mathrm{Mg}$ level and the SHIM-5 score $(p<0.05)$. The distribution of serum calcium values according to the groups was found as $9.60 \pm 0.60$ and $9.60 \pm 0.50$ $\mathrm{mg} / \mathrm{dL}$, respectively $(p=0.47)$. The distribution of the cholesterol value according to the groups was found as $203.93 \pm 40.91$ and $201.68 \pm 41.36 \mathrm{mg} / \mathrm{dL}$, respectively $(p=0.64)$. The distribution of fasting blood glucose according to the groups was found as
Table 1. Demographic characteristics of the ED group and the control group

\begin{tabular}{|l|c|c|c|}
\hline Group & $\begin{array}{c}\text { Group 1 } \\
(\mathbf{n}=155)\end{array}$ & $\begin{array}{c}\text { Group 2 } \\
(\mathbf{n = 1 8 9 )}\end{array}$ & $\mathbf{p}$ \\
\hline Age, (years) (mean \pm SD) & $63.15 \pm 8.90$ & $61.63 \pm 8.01$ & 0.101 \\
\hline BMI & $27.95 \pm 5.79$ & $27.74 \pm 5.04$ & 0.71 \\
\hline Waist circumference, (cm) & $99.64 \pm 9.88$ & $103.98 \pm 8.91$ & 0.42 \\
\hline Diabetes mellitus, (n)\% & $42(27.1)$ & $25(13.4)$ & $0.002^{\star}$ \\
\hline Pulmonary disease, (n)\% & $16(10.3)$ & $20(10.6)$ & 0.53 \\
\hline Hypertension, (n)\% & $64(41.3)$ & $63(33.7)$ & 0.17 \\
\hline Heart disease, (n)\% & $45(29)$ & $24(12.8)$ & $<0.001^{*}$ \\
\hline Smoking, (n)\% & $74(47.7)$ & $96(51.3)$ & 0.51 \\
\hline Alcohol consumption, (n)\% & $16(10.4)$ & $15(8)$ & 0.45 \\
\hline $\begin{array}{l}\text { SHIM-5 } \\
\text { *: (p<0.05) }\end{array}$ & $12.75 \pm 4.24$ & $19.59 \pm 3.52$ & $<0.001^{*}$ \\
\hline $\begin{array}{l}\text { SD: standard deviation; BMI: body mass index; SHIM: Sexual Health Inventory } \\
\text { for Men }\end{array}$ & & & \\
\hline
\end{tabular}

Table 2. Distribution of serum parameters of the groups

\begin{tabular}{|c|c|c|c|}
\hline Group & $\begin{array}{l}\text { Group } 1 \\
(n=155)\end{array}$ & $\begin{array}{l}\text { Group } 2 \\
(n=189)\end{array}$ & $p$ \\
\hline $\mathrm{Mg}{ }^{a} \mathrm{mg} / \mathrm{dL}$ (average) & $1.94 \pm 0.20$ & $2 \pm 0.17$ & $0.008^{*}$ \\
\hline Cholesterola $^{a}$ & $203.93 \pm 40.91$ & $201.68 \pm 41.36$ & 0.64 \\
\hline $\mathrm{FBS}^{\mathrm{a}}$ & $116.60 \pm 44.21$ & $104.77 \pm 14.08$ & $0.02^{\star}$ \\
\hline$W^{\prime a}$ & $6.94 \pm 1.74$ & $6.58 \pm 1.43$ & $0.04^{\star}$ \\
\hline CRPb & $0.15 \pm 0.29$ & $0.13 \pm 0.32$ & 0.66 \\
\hline Neu/Lym & $1.95 \pm 0.9$ & $1.70 \pm 0.97$ & 0.30 \\
\hline $\mathrm{Ca}$ & $9.60 \pm 0.60$ & $9.60 \pm 0.50$ & 0.47 \\
\hline \multicolumn{4}{|c|}{ a: median \pm IQR, b: mean $\pm S D, *:(p<0.05)$} \\
\hline \multicolumn{4}{|c|}{$\begin{array}{l}\text { FBS: fasting blood sugar; WBC: white blood cells; CRP: C-reactive protein; Neu/Lym: } \\
\text { neutrophil-lymphocyte ratio; SD: standard deviation }\end{array}$} \\
\hline
\end{tabular}

$116.60 \pm 44.21$ and $104.77 \pm 14.08 \mathrm{mg} / \mathrm{dL}$, respectively, and this change was statistically significant $(p=0.02)$. The CRP, WBC, and $\mathrm{Neu} / \mathrm{Lym}$ ratios were measured as inflammatory markers. The CRP was found as $0.15 \pm 0.29$ and $0.13 \pm 0.32 \mathrm{mg} / \mathrm{dL}$ for Group 1 and Group 2, respectively $(p=0.66)$. Likewise, the Neu/Lym ratio was $1.95 \pm 0.90$ and $0.13 \pm 0.32$, respectively $(p=0.30)$. The WBC values measured as inflammatory markers were $6.94 \pm 1.74$ and 6.58 \pm 1.43 for Group 1 and Group 2, respectively. The WBC score was found to be increased in Group 1, and this increase was statistically significant $(p=0.04)$ (Table 2 ).

\section{DISCUSSION}

To the best of our knowledge, our study is the first one to examine the relationship between $\mathrm{Mg}$ and ED. In this study, it was determined that the serum $\mathrm{Mg}$ level in patients with sexual dysfunction decreased in comparison to the control group. 
The erection depends on the sexual stimulation that initiates the synthesis of $\mathrm{NO}$ and other endothelial factors that cause relaxation in the smooth muscles of the arteries carrying blood to the erectile tissues (8-10). For this reason, endothelial integrity plays an important role in penile erection physiology. It plays a role in the synthesis of various endothelial compounds such as NO, in addition to many other functions, such as providing the functional integrity by lining the inner part of the vein, preservation of the vascular permeability, non-adhesion of the elements in blood to the vascular surface, and inhibition of thrombus formation in the vascular system (11). Therefore, any factor that causes endothelial dysfunction may initiate the ED development process. Cardiovascular diseases (CVD) are also known to develop on the basis of endothelial dysfunction. It has also been shown that aging and diseases such as, hypertension, hypercholesterolemia, diabetes and obesity, which cause endothelial dysfunction, are frequently found in the etiology of both diseases. In the light, ED and CVD are considered to be two different findings of the same systemic disease $(12,3)$. This association was first brought forward by Montorsi et al. (13). The authors reported that ED-related problems occurred in these patients at least 3 years before the onset of coronary artery disease. In addition, a correlation between ED and the severity of vascular diseases and mortality due to vascular diseases (stroke, heart failure, myocardial infarction, etc.) was also reported $(14,15)$. As a result, any factor that causes the development of vascular diseases can also trigger the ED development process.

Recently, Mg, known as a cofactor for many enzymes, has been associated with the emergence of many diseases. $\mathrm{Mg}$ is also a $\mathrm{Ca}$ antagonist (16). Studies have suggested that there is a close relationship between $\mathrm{Mg}$ and vascular diseases and that it has a protective effect against vascular diseases. Such as endothelin-1, this effect has been associated with suppressor effect against many factors showing agonistic effect in the development of vasoconstriction (17-19). In the case of endothelial damage, it also blocks abnormal coagulation by binding specific coagulation factors such as $\mathrm{Ca}$ (20). The control of abnormal coagulation is important in terms of many factors such as the viscosity of the blood, the maintenance of adequate blood flow to the tissues, and the inhibition of the development of atherosclerotic plaques. In a study conducted on this subject, Turgut et al. (21) investigated the relationship between $\mathrm{Mg}$ and the progression of atherosclerosis. The authors reported that $\mathrm{Mg}$ has a protective effect in the progression of atherosclerosis (21).

Another cause of endothelial or vascular dysfunction is vascular calcification (VC). VC develops in vascular smooth muscle cells, and it can lead to atherosclerosis or vascular dysfunction. Studies in this regard have reported that $\mathrm{Mg}$ has a protective effect against VC $(22,23)$. VC can explain the common cause of ED in the group with a low Mg level in our study. Previous studies have shown a close relationship between VC and ED. In one of these studies, Chiurlia et al. (24) reported that VC was more frequently observed in patients with ED compared to the control group. In another study, Yaman et al. (25) examined the relationship between coronary artery calcification and ED, and they found a correlation between coronary artery calcification and ED and the severity of ED. In the results of this study, it is seen that the $\mathrm{Mg}$ level is important for a healthy vascular structure and endothelial function. In our study, VC may be responsible for the development of ED. However, in our study, the VC-related data of the patients could not be reached, which is one of the study limitations.

Another reason for the relationship between $\mathrm{Mg}$ and ED in this study may be related to the effect of $\mathrm{Mg}$ on the vascular smooth muscle contraction. Vascular tonus plays a critical role in ensuring adequate blood flow to the tissues. During sexual stimulation, the relaxation in the smooth muscles of the arteries that supply blood to erectile tissues is important for erection (26). Studies on this subject have reported that $\mathrm{Mg}$ plays an important role in vascular tonus by the Ca-channel blockade in vascular smooth muscle cells $(27,28)$. In addition, the relationship has been reported between reduced Mg levels and abnormal growth of vascular muscle cell, muscle contraction, inflammation, and fibrosis (29). Therefore, the decrease in Mg level may reduce blood flow by causing vasoconstriction in blood vessels carrying blood to the erectile tissue.

Other studies have suggested that Mg levels correlate with insulin resistance, diabetes mellitus, hypertension, vascular disease, and metabolic syndrome $(30,31)$. These results are supported by other researchers. In these studies, the serum $\mathrm{Mg}$ level was reported to have decreased in patients with metabolic syndrome in comparison to the control group (32). For this reason, it has been suggested that $\mathrm{Mg}$ supplementation may protect against these diseases. In a study conducted on this subject, Song et al. (33) examined the effect of Mg supplementation on hypertension for 10 years. The authors reported that Mg supplementation has a protective effect against hypertension. In another study, Shahbah et al. (34) reported that diabetes and worsening lipid profile in children correlated with low Mg levels. In our study, serum Mg levels in diabetic patients were found to be significantly reduced compared to non-diabetic patients. Mg may contribute to the development of ED in relation to the metabolic syndrome. The development of ED in the group with a low Mg level supports this view in our study.

In some studies, a correlation was established between Mg levels and inflammatory changes. Thus, Ata et al. (35) in their study indicated that serum Mg levels decreased in smokers in the inflammatory process, which they showed with a CRP increase. Although not statistically significant in our study, CRP levels in the ED group were found to be higher than in the control group. In another study, Evangelopoulos et al. (36) compared serum Mg levels with high-sensitivity (hs)-CRP levels in obese patients. They found an inverse relationship between the Mg level and the hsCRP level. As a result, the authors reported that Mg supplementation could be useful in terms of the inflammation suppression. These study results clearly support the relationship between $\mathrm{Mg}$ and a low-level inflammatory process. It is also well known that an inflammatory milieu is an effective factor in all stages and in the progression of the atherosclerotic process (37). In short, the subclinical inflammatory process may affect endothelial functions, leading to the development of ED. An increase in the WBC value in the ED group, which has been found in our conclusions and which suggests an inflammatory process, supports this view. Similarly, the Neu/Lym ratio was also found to be increased in 
the ED (+) group compared to the non-ED group, although it did not reach a statistical significance. It has been reported in previous studies that there is a relationship between the onset or severity of ED and the inflammatory markers. There is chronic inflammation in the pathogenesis of the metabolic syndrome, as well, and studies have shown that inflammatory markers increase in diabetic and obese patients (11).

In our study results, it was observed that the ED complaints were more frequent in the group with low $\mathrm{Mg}$ than in the control group. We do not precisely know the reason for this. A disorder related to the relaxation that occurs in the smooth muscles of the arteries carrying blood to the erectile tissues may be endothelial dysfunction or a defect in the release of vasodilator compounds such as NO secreted from the endothelium. It may also be due to subclinical inflammation caused by the Mg deficiency or due to vascular disorder caused by metabolic syndrome. The demonstration of Mg's protective effect against vascular diseases in studies supports this view. In short, we think that a complicated pathologic process that develops as a result of magnesium deficiency and ends with endothelial dysfunction is associated with the development of ED.

There are some lacking fields in this study. The main limitations are that it is a retrospective study with a low number of patients and that the results were reported from a single center. In addition, only the serum Mg level has been measured in this study, and its intracellular value is not known.

\section{CONCLUSION}

This study determined that the serum Mg level was decreased in patients with ED compared to the control group. We think that a vascular endothelial disorder that occurs with the decrease in the serum Mg level creates a favorable environment for the development of ED. In addition, new studies can be planned in the future to examine whether the complaints will regress after determining the serum $\mathrm{Mg}$ value in these patients and supporting those patients with low levels. In addition, the serum Mg value can be used as a marker for the pre-detection of risky patients. However, there is a need for more extensive studies to be conducted in this regard to fully clarify this issue.

Ethics Committee Approval: Ethics committee approval was received for this study from the ethics committee of Ordu University (no: 40/2017).

Informed Consent: Due to the retrospective design of the study, informed consent was not taken.

Peer-review: Externally peer-reviewed.

Author Contributions: Concept - E.B, S.N.A.; Design - E.B, A.Ç.; Supervision - E.B.; Resources - E.B, A.Ç.; Materials - E.B., S.N.A.; Data Collection and/or Processing - E.B, A.Ç; Analysis and/or Interpretation - E.B, A.Ç, S.N.A.; Literature Search - A.Ç, E.B.; Writing Manuscript - E.B, S.N.A.; Critical Review - A.Ç, E.B.

Conflict of Interest: No conflict of interest was declared by the authors.

Financial Disclosure: The authors declared that this study has received no financial support.

\section{REFERENCES}

1. NIH Consensus Conference. Impotence. NIH Consensus development Panel on Impotence. JAMA 1993; 270: 83-90. [CrossRef]

2. Lewis RW, Fugl-Meyer KS, Corona G, Hayes RD, Laumann EO, Moreira ED Jr, et al. Definitions/epidemiology/risk factors for sexual dysfunction. J Sex Med 2010; 7: 1598-607. [CrossRef]

3. Fung MM, Bettencourt R, Barrett-Connor E. Heart disease risk factors predict erectile dysfunction 25 years later: the Rancho Bernardo Study. J Am Coll Cardiol 2004; 43: 1405-11. [CrossRef]

4. Montorsi P, Ravagnani PM, Galli S, Rotatori F, Briganti A, Salonia A, et al. The artery size hypothesis: a macrovascular link between erectile dysfunction and coronary artery disease. Am J Cardiol 2005; 96: 19-23. [CrossRef]

5. Cefaratti C, Romani AM. Functional characterization of two distinct $\mathrm{Mg}(2+)$ extrusion mechanisms in cardiac sarcolemmalvesicles. Mol Cell Biochem 2007; 303: 63-72. [CrossRef]

6. Reffelmann T, Ittermann T, Dörr M, Völzke H, Reinthaler M, Petersmann $A$, et al. Low serum magnesium concentrations predict cardiovascular and all-cause mortality. Atherosclerosis 2011; 219: 280-4. [CrossRef]

7. Kolte D, Vijayaraghavan K, Khera S, Sica DA, Frishman WH. Role of magnesium in cardiovascular diseases. Cardiol Rev 2014; 22: 182-92. [CrossRef]

8. Gratzke C, Angulo J, Chitaley K, Dai YT, Kim NN, Paick JS, et al. Anatomy, physiology, and pathophysiology of erectile dysfunction. J Sex Med 2010; 7: 445-75. [CrossRef]

9. Billups KL, Bank AJ, Padma-Nathan H, Katz SD, Williams RA. Erectile dysfunction as a harbinger for increased cardiometabolic risk. Int J Impot Res 2008; 20: 236-42. [CrossRef]

10. Jackson G, Montorsi P, Adams MA, Anis T, El-Sakka A, Miner M, et. Cardiovascular aspects of sexual medicine. Sex Med 2010; 7: 160826. [CrossRef]

11. Gandaglia G, Briganti A, Jackson G, Kloner RA, Montorsi F, Montorsi $P$, et al. A systematic review of the association between erectile dysfunction and cardiovascular disease. Eur Urol 2014; 65: 968-78. [CrossRef]

12. Feldman HA, Johannes CB, Derby CA, Kleinman KP, Mohr BA, Araujo $A B$, et al. Erectile dysfunction and coronary risk factors: prospective results from the Massachusetts male aging study. Prev Med 2000; 30: 328-38. [CrossRef]

13. Montorsi F, Briganti A, Salonia A, Rigatti P, Margonato A, Macchi A, et al. Erectile dysfunction prevalence, time of onset and association with risk factors in 300 consecutive patients with acute chest pain and angiographically documented coronary artery disease. Eur Urol 2003; 44: 360-4. [CrossRef]

14. Vlachopoulos C, Rokkas K, loakeimidis N, Aggeli C, Michaelides A, Roussakis $G$, et al. Prevalence of asymptomatic coronary artery disease in men with vasculogenic erectile dysfunction: a prospective angiographic study. Eur Urol 2005; 48: 996-1002. [CrossRef]

15. Böhm M, Baumhäkel M, Teo K, Sleight P, Probstfield J, Gao P, et al; ONTARGET/TRANSCEND Erectile Dysfunction Substudy Investigators. Erectile dysfunction predicts cardiovascular events in high-risk patients receiving telmisartan, ramipril, or both: The ONgoing Telmisartan Alone and in combination with Ramipril Global Endpoint Trial/Telmisartan Randomized AssessmeNt Study in ACE iNtolerant subjects with cardiovascular Disease (ONTARGET/TRANSCEND) Trials. Circulation 2010; 121: 1439-46. [CrossRef]

16. Tosiello L. Hypomagnesemia and diabetes mellitus. A review of clinical implications. Arch Intern Med 1996; 156: 1143-8. [CrossRef]

17. Vianello E, Dozio E, Barassi A, Sammarco G, Tacchini L, MarroccoTrischitta MM, et al. A pilot observational study on magnesium and calcium imbalance in elderly patients with acute aorticdissection. Immun Ageing 2017; 14: 1. [CrossRef] 
18. Reffelmann $T$, Ittermann $T$, Dörr M, Völzke $H$, Reinthaler M, Petersmann $A$, et al. Low serum magnesium concentrations predict cardiovascular and all-cause mortality Atherosclerosis 2011; 219: 280-4. [CrossRef]

19. Ko EA, Park WS, Earm YE. Extracellular Mg(2+) blocks endothelin1 -induced contraction through the inhibition of non-selective cation channels in coronary smooth muscle. Pflugers Arch 2004; 449: 195204. [CrossRef]

20. Tokutake T, Baba H, Shimada Y, Takeda W, Sato K, Hiroshima Y, et al. Exogenous Magnesium Chloride Reduces the Activated Partial Thromboplastin Times of Lupus Anticoagulant-Positive Patients. PLoS One 2016; 11: e0157835. [CrossRef]

21. Turgut F, Kanbay M, Metin MR, Uz E, Akcay A, Covic A. Magnesium supplementation helps to improve carotid intima media thickness in patients on hemodialysis. Int Urol Nephrol 2008; 40: 1075-82. [CrossRef]

22. Herencia C, Rodríguez-Ortiz ME, Muñoz-Castañeda JR, MartinezMoreno JM, Canalejo R, Montes de Oca A, et al. Angiotensin II prevents calcification in vascular smooth muscle cells by enhancing magnesium influx. Eur J Clin Invest 2015; 45: 1129-44. [CrossRef]

23. Kircelli F, Peter ME, Sevinc Ok E, Celenk FG, Yilmaz M, Steppan S, et al. Magnesium reduces calcification in bovine vascular smooth muscle cells in a dose-dependent manner. Nephrol Dial Transplant 2012; 27: 514-21. [CrossRef]

24. Chiurlia E, D'Amico R, Ratti C, Granata AR, Romagnoli R, Modena MG. Subclinical coronary artery atherosclerosis in patients with erectile dysfunction. J Am Coll Cardiol 2005; 46: 1503-6. [CrossRef]

25. Yaman O, Gulpinar O, Hasan T, Ozdol C, Ertas FS, Ozgenci E. Erectile dysfunction may predict coronary artery disease: relationship between coronary artery calcium scoring and erectile dysfunction severity. Int Urol Nephrol 2008; 40: 117-23. [CrossRef]

26. Gratzke C, Angulo J, Chitaley K, Dai YT, Kim NN, Paick JS, et al. Anatomy, physiology, and pathophysiology of erectile dysfunction. J Sex Med 2010; 72: 445-75. [CrossRef]

27. Ma J, Zhao N, Zhu D. Biphasic responses of human vascular smooth muscle cells to magnesium ion. J Biomed Mater Res A 2016; 104: 347-56. [CrossRef]
28. Bai Y, Zhang J, Xu J, Cui L, Zhang H, Zhang S, et al. Magnesium prevents $\beta$-glycerophosphate-induced calcification in rat aortic vascular smooth muscle cells. Biomed Rep 2015; 3: 593-7. [CrossRef]

29. Tammaro P, Smith AL, Crowley BL, Smirnov SV. Modulation of the voltage-dependent $\mathrm{K}+$ current by intracellular $\mathrm{Mg}^{2+}$ in rat aortic smooth muscle cells. Cardio vasc Res 2005; 65: 387-96. [CrossRef]

30. Kisters K, Spieker C, Tepel M, Zidek W. New data about the effects of oral physiological magnesium supplementation on several cardiovascular risk factors (lipids and blood pressure). Magnes Res 1993; 6: 355-60.

31. Kao WH, Folsom AR, Nieto FJ, Mo JP, Watson RL, Brancati FL. Serum and dietary magnesium and the risk for type 2 diabetes mellitus: the Atherosclerosis Risk in Communities Study. Arch Intern Med 1999; 159: 2151-9. [CrossRef]

32. Guerrero-Romero F, Jaquez-Chairez FO, Rodríguez-Morán M. Magnesium in metabolic syndrome: a review based on randomized, double-blind clinical trials. Magnes Res 2016; 29: 146-153.

33. Song Y, Sesso HD, Manson JE, Cook NR, Buring JE, Liu S. Dietary magnesium intake and risk of incident hypertension among middle-aged and older US women in a 10-year follow-up study. Am J Cardiol 2006; 98: 1616-21. [CrossRef]

34. Shahbah D, El Naga AA, Hassan T, Zakaria M, Beshir M, Al Morshedy S, Abdalhady M, Kamel E, Rahman DA, Kamel L, Abdelkader M. Status of serum magnesium in Egyptian children with type 1 diabetes and its correlation to glycemic control and lipid profile. Medicine (Baltimore) 2016; 95: e5166. [CrossRef]

35. Ata MA, Shaikh SS, Iqbal T, Hina, Jamil D, Khan R, et al. Inverse Correlation between Serum C-Reactive Protein and Magnesium Levels in Smokers and Nonsmokers. N Am J Med Sci 2015; 7: 271-4. [CrossRef]

36. Evangelopoulos AA, Vallianou NG, Panagiotakos DB, Georgiou A, Zacharias GA, Alevra AN, et al. An inverse relationship between cumulating components of the metabolic syndrome and serum magnesium levels. Nutr Res 2008; 28: 659-63. [CrossRef]

37. Hu J, Xi D, Zhao J, Luo T, Liu J, Lu H, et al. High-density Lipoprotein and Inflammation and Its Significance to Atherosclerosis. Am J Med Sci 2016; 352: 408-15. [CrossRef] 